\title{
FACTORS CAUSING PROBLEMS IN MANAGING CONSTRUCTION PROJECTS IN A COUNTRY UNDER MILITARY OCCUPATION: CONTRACTORS’ PERSPECTIVE
}

\author{
Akram Subhe Suleiman ${ }^{1}$, Arkam M. Zeki Mohamad ${ }^{2}$ \\ Jafar Subhi Hardan Abahre ${ }^{3}$ \\ ${ }^{1,2}$ Assistant Professor, Department of Civil Engineering, College of Engineering, Al Isra University, Amman, \\ Jordan, \\ ${ }^{3}$ Assistant Professor, Department of Tourism and Archeology, Faculty of Humanities, An-Najah National \\ University, Palestine \\ 1'akram.suleiman@iu.edu.jo, ${ }^{2}$ arkam.mohammad@iu.edu.jo, ${ }^{3}$ abahre@najah.edu
}

\begin{abstract}
An exhaustive literature search revealed that not much research has been done on factors causing problems in managing a construction project in a country under military occupation like Palestine. So, it is the main goal of this research is to identify these factors which could be used by the decision makers to select the appropriate project manager who bosses the suitable skills and competencies to deal with these problems. The study is a step toward determining means to improve the effectiveness of projects through identifying project manager competencies. It is important for Palestinian construction industry to progress in terms of project success; the problems that face the project managers must be determined and identified, in order to achieve the best results with less risk. A clear understanding of such problems helps the Palestinian construction industry of finding the suitable solutions to overcome these problems. A questionnaire survey was carried out to achieve the main aim of this research. The respondents were engineers have more than 3 years in the position of project manager in the Palestinian construction industry. The survey was based on factors drawn from findings of another researches in different countries, together with special factors identified as potentially affecting Palestine. The results identified many factors created problems; they were clustered in eight groups. These groups were arranged according to respondents in descending order as follows: the political situation of Palestine, lack of consultants 'technical competencies, lack of resources, insufficient planning, team members uncommitted, conflicts between departments, breakdowns in communications, and changes in goals. As a result of this study one could conclude that managing a project in Palestine is as difficult as the complication of the political situation of the country. The project manager should have a complicated mixture of skills and competencies from dealing with Israeli occupation to dealing with stakeholders to lack of resources and unclear goals. The study has recommended to the Palestinian government to improve the regulations and laws to meet the impact of closure and segmentation of the Palestine.
\end{abstract}

Keywords: Construction Industry, Palestine, Military Occupation, Project Managers.

\section{INTRODUCTION}

The West Bank and the Gaza Strip are parts of Palestine- occasionally these territories are also referred to as Palestine or Occupied Palestine. After the 1967 Arab-Israeli war, Israel occupied West Bank and the Gaza Strip. The occupation continued from that time until the peace treaty between Israel and the Palestine Liberation Organization (PLO) in 1993, which led to the Oslo agreement.

The construction sector is one of the main economic engine sectors supporting any national economy; it plays a central role in national welfare, including the development of residential housing, office buildings and industrial plants, and the restoration of the nation's infrastructure and other public facilities. The importance of this industry lay in the function of its products which provide the foundation for industrial production Hendrickson [1]. In the United States, the construction industry is considered to be the largest in the world accounting for 25 percent of the total global construction industry. The same situation in Palestine, the construction industry is considered one of the principal sectors that contribute strongly to the Palestinian 
economy. Based on data from PCBS [2], it was found that the average contribution of the construction industry to Palestinian gross domestic product (GDP) ranged from 2.18 percent to 2.68 percent during the period from 2000 to 2006. In 2007 alone, this industry employed 11.6 percent from the local workforce Enshassi et al. [3]. The sector has played a vital role in extending job opportunities for the Palestinian labor force; its expansion has generated many jobs for skilled, semiskilled and unskilled workers.

Despite the substantial success achieved by the construction industry in the Palestinian territories, in terms of economic growth, its contribution to the local output, employment and meeting partially the local needs of the Palestinian society, this industry suffers from a number of problems that have prevented it from resuming its big role in the Palestinian economy (Enshassi et al. [4]. Unlike developed countries, Palestine does not have a mature construction industry with well-established contracting and consulting companies. Much of the building and construction is done by the informal sector Enshassi et al. [4].

This sector is susceptible to the political situation and to the trends of international donations. It is featured by highly intermittent temporary employment rates PFI [5]. The construction sector in Palestine was one of the leading sectors that achieved high rates of economic growth in the 1970s and up to the mid-1980s. During that period of time, the contribution of this sector has increased in terms of providing job opportunities for the Palestinian labor force and the generation of local production. Since then, this sector has been subjected to many setbacks which have decreased its role in building up the Palestinian economy in contrast with its counterparts in many developing and neighboring countries Enshassi et al. [4]. The pressure on contractors bidding decisions has further increased in the last five years due to the current political situation, which causes a sharp decrease in the number of the available projects Enshassi et al. [6]. Mahamid [7] found five factors as being highly influential with huge potential to cause the failure of contracting businesses which are fluctuation in the cost of construction materials; delay in collecting payments from clients; lack of experiences in contracts; low margin of profit due to competition; and closure and limitation of movement between West Bank areas.

A survey of contractors, consultants, and owners was conducted by Enshassi et al. [8] to elicit their opinions regarding causes of delays and cost overruns in construction projects in Palestine. Results indicated that the most important factors that cause time overruns are strikes, external or internal military action and border closures, lack of materials in markets, delay of material delivery to site, cash flow problem during construction, shortage of construction materials at site, poor site management, no adherence to materials standards relating to site storage, poor economic conditions (currency, inflation rate, etc.), major disputes and negotiations and suspension of work by owner or contractor. Suleiman [9] investigated the awareness of consulting and contracting project managers in the Palestinian construction industry on the importance of training programs related to project management. The research revealed that most of Palestinian project managers realized the importance of the training programs to the project management. Furthermore, the outcome suggests that the achieved training programs by the consulting project managers were statistically significantly higher than that achieved by contracting project managers. The study recommends to construction industry bodies to take the benefit of homogeneity of the research in developing and implementing strategies for improvement and innovation in training programs related to project management. Another research by Mahamid [10] aimed to identify the risk matrix for factors affecting delays in road construction projects in the West Bank in Palestine from the owners' perspective. The results identified eight severe factors that are located in the red zone which are: poor communication between construction parties; poor resource management; delay in commencement; insufficient inspectors; rework from poor material quality; rework from poor workmanship; payments delay; and segmentation of the West Bank

\section{Project Manager Competencies and Problems in Managing Projects}

This study is a step toward determining problems facing project managers during managing their construction project which would help the construction industry to select the best project manager who can deal with these problems effectively. Several researches have shown that construction project managers play a vital role in the success or failure of a project [11-14]. Crawford [11] was one of the first to establish a link between project managers and project success. Additional studies have concluded that project managers play an important part in project success or failure $[13,14]$. Many researchers have focused on the construction project manager's characteristics and competencies that help achieve project success. An effective project manager exhibits certain competencies, and it is these competencies that play a key role in the outcome of any project [15]. In addition, successful construction organizations now focus on ensuring that project managers acquire the core competencies required to be successful in their assignments [16]. An organization can maximize its probability of consistently attaining project success by recruiting, developing, nurturing and retaining superior project managers [17].

It is an indirect goal of this study to identify the competencies needed to be an effective project manager in the Palestinian construction industry. The problems that face the project managers must be determined and identified, in order to achieve the best results with less risk, good quality, and finishing the projects within time, 
quality and cost constraints. Daniel Roman [18] maintains that it would take an extraordinary individual to have all of these critical personal characteristics. A more practical solution, he suggests, would be to determine the critical problems faced by project managers and select a person who can handle such difficulties. Roman actually is raising two different issues; one is good project managers understand the critical problems that face them and are prepared to deal with them, the second is managing projects well requires a set of particular attributes and skills.

Barry Z. Posner [19] addressed nearly nine hundred statements about what factors or variables created "problems" in managing a project. These problems were clustered into eight categories. The five groups are: Resources inadequate, meeting unrealistic deadlines, unclear goals/direction, team members uncommitted, insufficient planning, breakdowns in communication, changes in goals and resources, and finally conflicts between departments or functions. Posner's eight categories were adopted to achieve the goals of this research with some modifications well-suited with Palestine. Finally, a clear understanding of such problems helps the Palestinian construction industry in finding suitable solutions to overcome these problems.

\section{RESEARCH METHODOLOGY}

This research utilized a questionnaire survey to collect a primary data from construction project managers in Palestine. The questionnaire was structured to collect the general and technical background of project managers in the Palestinian construction industry, the general profile of the Palestinian construction firms, and to elicit the main factors to cause problems in managing a project. Therefore, the questionnaire contained three parts. The major part of the questionnaire contains the main question of the study which is what factors are most likely to cause problems in managing a project? The questionnaire survey was designed to be easy, convenient, less time consuming and interesting as possible. The questionnaire was translated into the Arabic language from the English version and back-translation was carried out, this was done to assist the respondents in answering the questionnaire.

The targeted population of this research is the contractors' project managers working in the construction industry in Palestine. Based on the data obtained from PCU (2016) regarding the numbers of Palestinian's contracting firms, the total population of this research is 309 . To determine the sample size for the total population of the Palestinian contractors, Kish equation was used:

$$
\mathrm{n}=\frac{\mathrm{n}^{`}}{\left(1+\frac{\mathrm{n}^{\prime}}{\mathrm{N}}\right)}
$$

Where $\mathrm{n}^{\prime}$ is the sample size from an infinite population, which can be calculated from this formula $\left(\mathrm{n}^{\prime}=\right.$ S2/V2). The definitions of all variable can be defined as the following:

$\mathrm{n}=$ sample size from a finite population.

$\mathrm{N}=$ total population (309).

$\mathrm{V}=$ standard error of sample population equal 0.05 for the confidence level 95 percent, $\mathrm{t}=1.96$.

$\mathrm{S} 2=$ standard error variance of population elements, $\mathrm{S} 2=\mathrm{P} *(1-\mathrm{P})$; maximum at $\mathrm{P}=0.5$.

The sample size for the Palestinian contractors' population was calculated from the previous equations and found to be approximately 75 .

An initial pilot study was carried out in this research to test lucidity, accuracy, to check for the relevance and validity of the questions asked, and for any ambiguities. In order to ensure validity of the questionnaire, approximately 10 samples were conducted with key professional personnel who have had a long experience in the construction industry.

A simple random sampling was adopted, 75 questionnaires were sent to contracting firms, and 38 questionnaires were returned which all respondents were project managers, yielding a response rate of 50 percent.

\section{RESULTS AND DisCUSSION}

The collected data was processed by using Statistical Package for Social Science (SPSS) program. The Descriptive Statistics were used to evaluate the background of the respondents, and the background of the firms and the main study question. Microsoft Excel was used to draw the output Figures.

\section{A. BACKGROUND OF THE RESPONDENTS}

Table (1) shows the distribution of the respondents according to their demographic background. More than 89 percent of the respondents obtained an engineering qualification. 84.2 percents were bachelor degree holders, master's $(5.3 \%)$ and 10.5 percent have no formal education. Majority of the respondents were male $(89.5 \%)$ and aged between 31 to 40 years old (47.4\%); this means a medium period of experience needed in order to attain the status of project management within the construction in Palestine. This could be explained by the small size of the Palestinians firms, small size of projects, the political situation of Palestine, and the availability of Palestinian project managers in quality and quantity. The majority of project managers in the Palestinian 
construction industry $(70 \%)$ have working experience prior attaining their position less than 10 years, $19.8 \%$ have 11-20 years, and 9.4\% more than 21 years. 31.6 percent of respondents have 1 to 3 years of experience as project manager, 4 to 6 years $(28.9 \%)$ and 7 to $10(13.2 \%) .26 .3$ percent of the respondents were also working as project manager for more than 10 years. Approximately half of project managers $(47.4 \%)$ currently manage between $2-3$ projects, and $28.9 \%$ of respondents managing more than 5 projects.

Table 1: Background of the Respondents

\begin{tabular}{|c|c|c|}
\hline Variable & Frequency & Percentage \\
\hline \multicolumn{3}{|c|}{ Academic Qualification } \\
\hline Engineering & 34 & $89.5 \%$ \\
\hline Diploma & 2 & $5.3 \%$ \\
\hline No Formal & 2 & $5.3 \%$ \\
\hline \multicolumn{3}{|c|}{ Education Background } \\
\hline Bachelor degree & 32 & $84.2 \%$ \\
\hline Master's & 2 & $5.3 \%$ \\
\hline None & 4 & $10.5 \%$ \\
\hline \multicolumn{3}{|l|}{ Age } \\
\hline$<30$ years old & 8 & $21.1 \%$ \\
\hline 31 to 40 years old & 18 & $47.4 \%$ \\
\hline 41 to 50 years old & 7 & $18.4 \%$ \\
\hline$>50$ years old & 5 & $13.1 \%$ \\
\hline \multicolumn{3}{|l|}{ Gender } \\
\hline Male & 34 & $89.5 \%$ \\
\hline Female & 4 & $10.5 \%$ \\
\hline \multicolumn{3}{|c|}{ Experience as Project Manager } \\
\hline $1-3$ years & 12 & $31.6 \%$ \\
\hline 4-6 years & 11 & $28.9 \%$ \\
\hline $7-10$ years & 5 & $13.2 \%$ \\
\hline More than 10 years & 10 & $26.3 \%$ \\
\hline \multicolumn{3}{|c|}{ Current Number of Projects Managed by the Respondent } \\
\hline 1 & 2 & $5.3 \%$ \\
\hline $2-3$ & 18 & $47.4 \%$ \\
\hline $4-5$ & 7 & $18.4 \%$ \\
\hline MORE THAN 5 & 11 & $28.9 \%$ \\
\hline
\end{tabular}

\section{B. BACKGROUND OF THE FIRMS}

Most of the contracting firms were small firms with less than 20 employees (57.9\%), 15.7 percent of the firms have 21 to 40 employees, 41 to 60 employees (5.3\%) and more than 60 employees (21.1\%), these results could be explained by the small number and the low cost of the projects, and most of the firms 'general managers are the owners of that firms and they are also working as project managers.

\section{FACTORS CREATED PROBLEMS IN MANAGING PROJECTS}

This section attempted to achieve the main objective of this study, which is answering the main research question: what factors are most likely to cause you problems in managing a project in the Palestinian construction sector? The respondents were asked to answer the question by selecting yes or no. Frequencies and percentages were calculated directly using SPSS. Table 2 and Figure 1 show the results of the question.

The results showed that $100 \%$ of project managers considered the political situation of Palestine is the most important factor caused problems in managing a construction project, $84.2 \%$ of respondents considered lack of consultant project managers' competencies is the second factor caused problems in managing a construction project in Palestine, conflict between departments were considered the third factor creates problem in managing a project in Palestine with 76.3 percent.

Approximately $60.5 \%$ of respondents considered both lack of resources and team members uncommitted as the forth factor caused problems in managing a construction project, half of contractors considered insufficient planning as the fifth factor created problems in managing a construction project in Palestine. Breakdown in 
communication and changes in goals were selected by $47.4 \%$ and $34.2 \%$ of the respondents respectively as the least factors causing problems.

The results are in consistent with many researches regarding the critical political situation of Palestine, which was considered by many researchers as one of top critical problems facing progress and development of the Palestinian construction industry, Enshassi et al. [3] ranked political situation as one of the top five important factors affecting the contractor's strategies, arrangements and decision to participate in tenders or not. Mahamid [7] stated that one of the top factors that has highly influential with huge potential to cause the failure of contracting businesses in Palestine is the closure and limitation of movement between West Bank areas. In addition, Enshassi et al. [6] revealed that borders closure and blockade is the second factor has affect cost estimate accuracy in the Palestinian construction industry. Osaily [21] tried to clarify and prioritize the key barriers to implementing sustainable construction in Palestine. The results illustrated that political situation was the major barrier that prevents implementing sustainable construction.

Table 2: Percentages of Factors Created Problem

\begin{tabular}{|l|c|c|}
\hline \multicolumn{1}{|c|}{ Factors Group } & Frequency & Percentage \\
\hline The Political Situation & 38 & 100.0 \\
\hline Lack of Consultants` Technical Competencies & 32 & 84.2 \\
\hline Conflict between Departments & 29 & 76.3 \\
\hline Lack of Resource & 23 & 60.5 \\
\hline Team Members Uncommitted & 23 & 60.5 \\
\hline Insufficient Planning & 19 & 50.0 \\
\hline Breakdown in Communications & 18 & 47.4 \\
\hline Changes in Goals & 13 & 34.2 \\
\hline
\end{tabular}

The second problem facing Palestinian contracting project managers is lack of consultants' competencies. This finding reveals the importance of a future research which is identifying the competencies of project managers in Palestine and has been accomplished by the researcher in 2015. Lack of competencies is considered by many researchers as one of the main causes of construction problems. Enshassi et al. [8] stated that the professional management group of delay factors was ranked high by contractors as a main cause of delays and cost overruns in the construction projects in the Gaza Strip of Palestine. Yong \& Mustaffa [22] found that contractor's competence and experience is one of the top five critical success factors for construction projects in Malaysia. Mahamid [7] found the top four factors have highly influential with huge potential to cause the failure of contracting businesses in Palestine are human-related. 


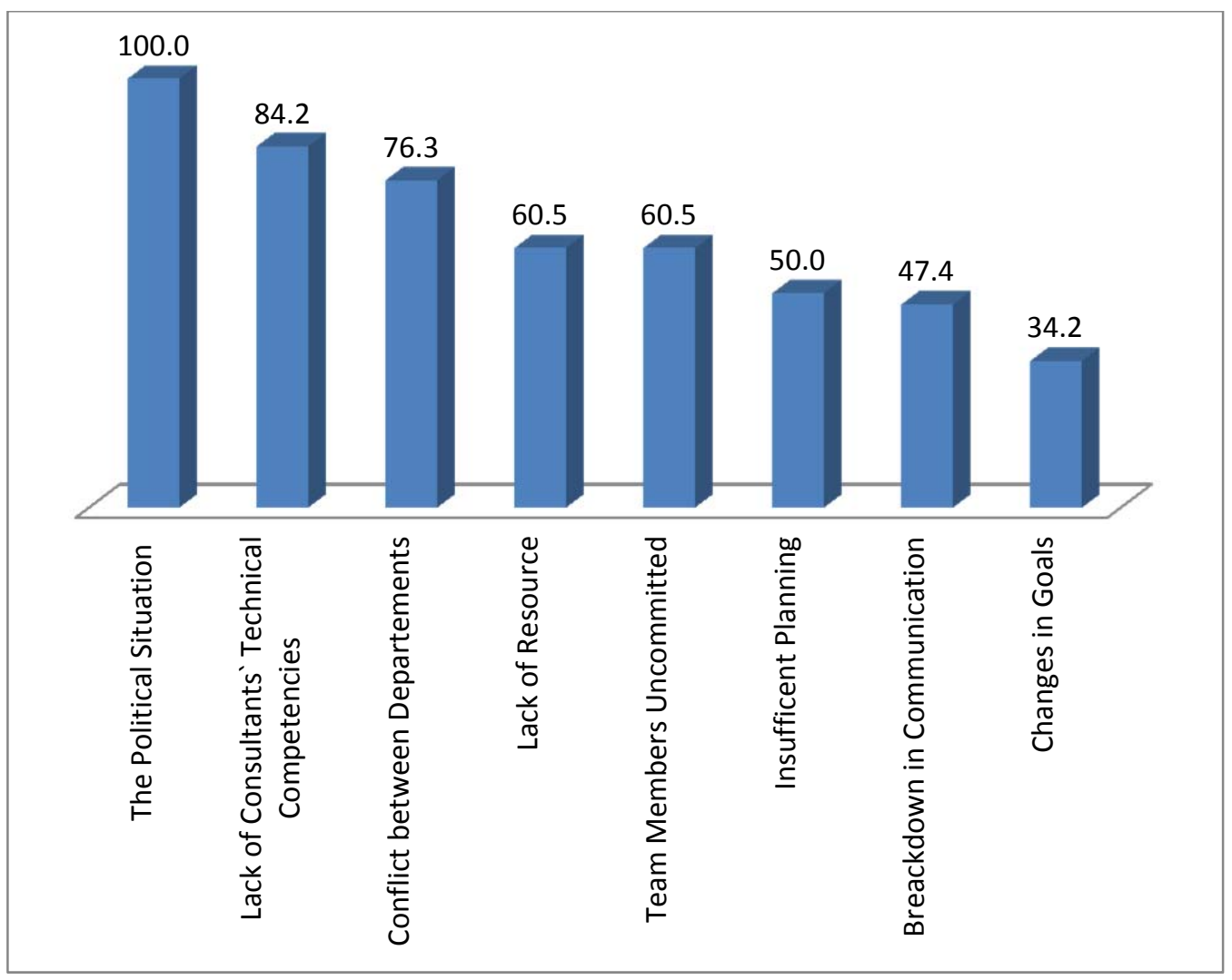

Fig. 1. Percentage of Factors Created Problems in Managing a Construction Project

\section{CONCLUSIONS AND RECOMMENDATIONS}

Factors caused problems in managing a construction project in Palestine have been identified and ranked. They are eight groups ranked as follows from the most to the least important: The political situation, lack of consultants' competencies, conflict between departments, lack of resources, team members uncommitted, insufficient planning, breakdown in communication, and finally changes in goals.

The political situation of Palestine is critical and complicated as a result of Israeli occupation, acing this problem is difficult to be solved by the Palestinians alone as an international help is needed. But the contracting firms should consider this problem in the bidding and in every stage of the construction project. The Palestinian Authority must improve the regulations and laws to meet the impact of closure and segmentation of the West Bank.

The problem of lack of competencies among consultants' project staff could be solved by recommending some policies to the donors and the Palestinian Authority in the prequalification of the Palestinian firms. They are recommended to select and recruit project managers according to their competencies and their managerial abilities, this procedure helps them improve and solve some frequent problems in their projects. Conflict between departments could be solved by activating the FIDIC standards between the construction parties.

Lack of resources in Palestine is a common problem as a result of the political situation, but it should be considered by the clients and donors in the project planning and designing stage. The problem of team members uncommitted could be related to the availability of job opportunities in Israel, the labors are ready to leave the work in Palestine and move to work in Israel due to high wages there. The contracting firms must review the wages and raise them at least half of wages in Israel.

Insufficient planning problem can be solved through increasing project planning process duration; it is the responsibility of the client to allow the designer and the contractor to take their time in the planning process of the construction project. it is recommended to the Palestinian universities and institutes to establish academic programs related to project management especially project planning. Regarding the problem of breakdown in communication it is important to the project stakeholders to know it is project manager first duty to manage communication in the project, so project managers may work on this competency to improve it through training and practice.

Finally, changes in goals is last problem in managing a project in Palestine, this problem could be a result of the previous problem which is insufficient planning. It is the first step in the project initiating process which is developing project charter which includes collecting and defining scope. So it is recommended to the clients to 
put clear goals at the beginning of each project, and they must try not to change these goals during project execution process

\section{RECOMMENDATIONS FOR FUTURE STUDIES}

This study identified the main problems facing the project managers while managing the construction projects, so it is recommended for further studies to identify the problems facing the project managers from the perspective of other organizations such as donors, government associations, and NGOs. The future studies may target other professionals such as electrical, mechanical, or architectural engineers who are involved in the construction industry. Finally, it is recommended to carry out in depth studies about these problems.

\section{REFERENCES}

[1] Hendrickson, C. "Project Management for Construction Fundamental Concepts for Owners, Engineers, Architects and Builders". Version 2.2, prepared for World Wide Web publication. Retrieved June 11, 2012, from http://pmbook.ce.cmu.edu/, 2008

[2] Palestinian Central Bureau of Statistics. Press Report. "Preliminary Estimates of Quarterly National Accounts". First Quarter, Ramallah, Palestine, 2006

[3] Enshassi, A., Mohamed, S. \& El Karriri, A. "Factors affecting the bid/no bid decision in the Palestinian construction industry". Journal of Financial Management of Property and Construction, Vol.15, No.2, 118-142, 2010

[4] Enshassi, A., Al-Hallaq, K. \& Mohamed, S. "Causes of Contractor's Business Failure in Developing Countries: The Case of Palestine". Journal of Construction in Developing Countries, Vol.11, No.2, 2006

[5] Palestinian Federation of Industries. "The Current Status of the Industrial Sector in Palestine:, 2009

[6] Enshassi, A., Arain, F. \&Taye, B. "Major causes of problems between contractors and subcontractors in the Gaza Strip". Journal of Financial Management of Property and Construction, Vol.17, No.1, 92-112, 2012

[7] Mahamid, I. "Factors affecting contractor's business failure: contractors' perspective". Engineering Construction and Architectural Management. Vol.19, No.3, 269-285, 2012

[8] Enshassi, A., Al-Najjar, J. \& Kumaraswamy, M. "Delays and cost overruns in the construction projects in the Gaza Strip". Journal of Financial Management of Property and Construction, Vol.14, No.2, 126-151, 2009

[9] Akram Subhe Suleiman. "The realization of Palestinian construction project managers on the importance of project management training programs". International Journal of Advanced Academic Research (Engineering), Vol.2, No.1, 2016

[10] Mahamid, I. "Risk matrix for factors affecting time delay in road construction projects: owners' perspective". Engineering, Construction and Architectural Management, Vol.18, No.6, 609-617, 2011

[11] Crawford, L. "Project management competencies for the new millennium". Proceedings of 15th World Congress on Project Management, London, England, IPMA, 2000

[12] Jiang, J. J., Klein, G., \& Chen, H. "The relative influence of IS project implementation policies and project leadership on eventual outcomes". Project Management Journal, Vol.32, No.3, 49-55, 2001

[13] Cooke-Davies, T. "The real success factors on projects". International Journal of project management, Vol.20, No.3, 185-190, 2002

[14] Nicholas, J., \& Hidding, G. "Management principles associated with IT project success". International Journal of Management and Information Systems, Vol.14, No.5, 147- 156, 2010

[15] Stevenson, D. H., \& Starkweather, J. A. "PM critical competency index: IT execs prefer soft skills". International Journal of Project Management, Vol.28, No.7, 663-671, 2009

[16] Hwang, B.G., and Ng, W.J. "Project management knowledge and skills for green construction: Overcoming challenges". International Journal of Project Management. 31, 272-284, 2013

[17] Sears, S.K., Sears, G.A., and Clough, R.H., "Construction Project Management: A Practical Guide to Field Construction Management", 5th edition. NJ, USA: Wiley, Hoboken, 2008

[18] Roman, D. D. "Managing Projects: A Systems Perspective". New York: Elsevier Science Publishing, 1985

[19] Barry Z. Posner. "What It Takes to Be a Good Project Manager". Project Management Journal Vol.18, No.1, (March, 1987

[20] Palestinian Contractors Union. "Construction Sector Profile". Retrieved June, 15, 2016 from http//www.pcu.ps/e/index.php?action=sector, 2016

[21] Osaily, N. Z. "The key Barriers to Implementing Sustainable Construction in West Bank - Palestine". Unpublished master thesis. Robert Kennedy College, Zurich. University of Wales, UK, 2010

[22] Yong, Y. C., and Mustaffa, N. E. "Critical success factors for Malaysian construction projects: an empirical assessment". Construction Management and Economics, Vol.31, No.9, 151-161, 2013

\section{AUTHOR PROFILE}

AKRAM SUBHE SULEIMAN Assistant professor at the school of civil engineering at Al Isra University in Jordan, he has more than seven years experience in the field of construction project management in the Arabian gulf area, and has three years academic experience in teaching many construction project management courses in the school of infrastructure and civil engineering. 